\title{
History of the Oscar Freire Institute
}

\author{
Daniel Romero Muñoz ${ }^{1}$, Ivan Dieb Miziara ${ }^{2}$, Marcela Valério Braga ${ }^{3}$
}

$\mathrm{T}$ he current building of the Oscar Freire Institute (Instituto Oscar Freire - IOF) was built on April 18, 1918 It received this name in the minutes of the extraordinary session of the this Faculty's Congregation, held on January 16, 1923. The name of the Institute is a posthumous tribute to Professor Dr. Oscar Freire de Carvalho, who began his carreer in Legal Medicine and Medical Ethics in 1918. From March 21, 1989 on, as of the Resolution 3498 of the Dean's Office of the University of São Paulo, it was renamed to Department of Legal Medicine, Medical Ethics and Social and Occupational Medicine, but up to these days most people know it by its well-known and traditional name of Oscar Freire Institute ${ }^{1}$.

The IOF, located in a building inserted in the complex of USP's Faculty of Medicine (FMUSP), next to the central block houses, in addition to the Department of Legal Medicine, Medical Ethics and Social and Occupational Medicine, one of the only Legal Medicine Museums in our country, with historical pieces and material related to relevant examinations performed at FMUSP or with its participation. The last important piece added to the museum was the skeleton of Josef Mengele, a physician tried and sentenced in absentia as a war criminal by the Nuremberg Trials.
The Department is now a complex with four major areas of medical knowledge (Legal Medicine, Occupational Medicine, Bioethics and Physical Medicine and Rehabilitation) and its mission is to be the trendsetter in education and training of specialized personnel in the development of research and multidisciplinary studies and in the introduction of new methods in the areas of its competence. It is actively involved with society and has done so through partnerships with public and private bodies, generating knowledge to support the elaboration, or improvement and/or modification of concepts of current standards and public policies. It also edits, The Saúde, Ética \& Justiça (the name of the magazine is Health, Ethics \& Justice - www.revistas.usp.br/sej), included in USP's portal of journals (Portal de Revistas USP - USP Portal of Journals).

It has two services that focus on community service: the Center for Studies and Assistance Related to Sexual Abuse (Centro de Estudos e Atendimento Relativos ao Abuso Sexual - CEARAS) and the Occupational Health Service of the FMUSP's Clinical Hospital (Serviço de Saúde Ocupacional do Hospital das Clínicas da FMUSP - SSO).

\footnotetext{
1. Head Professor, Department of Forensic Medicine, Medical Ethics, Social and Occupational Medicine of the Hospital das Clínicas of the Medical School of the Universidade de São Paulo (University of São Paulo).

2. Associate Professor, Department of Forensic Medicine, Medical Ethics, Social and Occupational Medicine of the Hospital das Clínicas of the Medical School of the Universidade de São Paulo (University of São Paulo).

3. Medical Instructor, Department of Forensic Medicine, Medical Ethics, Social and Occupational Medicine of the Hospital das Clínicas of the Medical School of the Universidade de São Paulo (University of São Paulo).

Mailing adress: Av. Dr. Arnaldo, 455. Cerqueira César. São Paulo, SP. Email: danielmunoz@bol.com.br
} 
The CEARAS offers assistance to the families and to the sexual offenders, especially those involved in incest, referred by the Law. The CEARAS performs an average of 500 attendances per year. These attendances are carried out by psychologists and psychiatrists. Clinical experience shows a type of sexual abuse that is not usually reported: the abuse committed by the mothers in incestuous families. Although it is not reported nor perceived as such, we believe that this type of abuse can be as serious or more serious than the manifest incestuous sexual relationships. CEARAS - the University of São Paulo's Center for Studies and Assistance Related to Sexual Abuse (Centro de Estudos e Atendimento Relativos ao Abuso Sexual da Universidade de São Paulo) - has been working with these issues related to incest since 1993 through the study of this theme and mental health care to incestuous families referred by the Law. Society in general and government agencies have started to mobilize in an attempt to establish strategies for attending situations of sexual abuse. There is, in these instances, the perception of little or no preparation of health professionals who can deal with these issues. We believe that the relationship of trust is structuring in the relationships between health professionals and patients, where ethics and legal duty are two different instances. The debate on these issues related to the role of confidentiality for health professionals in the assistance to cases of interfamilial sexual abuse and the consequent reflection on bioethics and incest are the basic objectives of this work ${ }^{2}$.

The SSO provides assistance to community workers who have occupational diseases. It offers Occupational Health, Mental Health at Work, Physical Medicine and Rehabilitation, Occupational Dermatology and Occupational Audiology attendances, in addition to procedures such as audiometry, impedanciometry and psychological tests. The SSO performed, in the last two years, 5396 attendances including medical consultations, consultations with non-medical professionals and other procedures. The activities developed in this Service are related to assistance in diagnosing and properly directing the occupational diseases and guiding workers regarding ways to prevent occupational diseases. One of the SSO's most important social function is instruct workers about social security rights, analyzing the work situations that may cause harm to health of workers, advising public and private Institutions, as well as unions from the area of Occupational Health. In addition to assistance activities, the SSO participates in Undergraduate and Graduate education in the Worker's Health area. Regarding research, the SSO aims to develop research in the Worker's Health area.

In the undergraduate teaching area, the Department accounts for a substantial fraction of the workload of the undergraduate Medical course, teaching 7 compulsory courses and seven elective courses. The compulsory courses are: Humanistic Foundations of Medicine I, Humanistic Foundations of Medicine II, Social and Occupational Medicine, Citizenship and Medicine, Bioethics, Legal Medicine and Clinical Bioethics. The elective courses are: Autonomist Focus of Bioethics: Ethical Reflections without A Priori Concepts, DNA Polymorphisms: Concepts and Applications in Legal Medicine, Occupational Anamnesis: from the Worker to the Patient, Stress and Work, Hearing Loss Induced by Noise, Medical Examination and Principles in Physiatrics.

The workload of compulsory and elective courses is distributed in such a way that the undergraduate student can leave Medical school with both the training necessary for the proper Medical practice and more thorough concepts in forensic sciences so that they can provide support to his or her professional practice.

Is is not possible to compare our Department with its national counterparts since there are no departments with such a structure in other Medical schools in the country. In terms of subject, the Legal Medicine of our Department stands out in Brazil. In fact, its faculty is usually required to teach courses in other schools. A comparison between the teaching of Legal Medicine in the undergraduate course with the teaching in other countries can only be done for those countries whose Law structure is similar to Brazil's, which is the case for Spain and Portugal. And it was observed that the subject is sufficient and equivalent to renowned departments such as those of Coimbra and of the Complutense University of Madrid, with which the IOF maintains exchanges

The Department has international performance in specialized education and especially in research with numerous universities abroad. Among them are the Vanderbilt University, University of Denver, University of Toronto, Florida International University, London School 
of Hygiene and Tropical Medicine, National University of Singapore, Nanyang University of Singapore, Umea University.

In 2015, the Department's Toxicology Laboratory has signed a collaboration agreement with the Johns Hopkins Internatinal Injury Research Unit in the Bloomber Initiative for Global Road Safety (BIGRS) project's research activities. This project is related to the World Health Organization (WHO).

In Bioethics, few schools have the subject distributed throughout the undergraduate course, as happens in our school. Bioethics, as a branch of philosophy that focuses on issues related to health and human life, is closely linked to the idea of justice and equality.

The inclusion of the Clinical Bioethics subject brought a new dimension to teaching where clinical situations are discussed from an ethical approach, with active participation of students in the preparation of these discussions, selecting cases, pointing out situations and difficulties from their hospital experience. The seminars are held in several clinics throughout the internship period (5th medical year).

In the Social and Occupational Medicine course students are faced with the daily occupational realities of the workers, participating in monitored visits to factories and companies where the health care systems and the main occupational diseases are presented and discussed. In recent years the area of Health and Occupational and has been accepting undergraduate scientific initiation students or students linked to the Medical Scientific Methodology course so that, in addition to the specific topics of the course, it can develop research capacity in the students, including the extension activities of the Occupational Health Service with the search for new knowledge.

The Institute includes the only Legal Medicine Residency Program approved by the National Commission of Medical Residency (Comissão Nacional de Residência Médica - CNRM) of the Ministry of Education to date, which began to be developed in 2004. The program is three years long and has five positions accredited by the CNRM per year. The first stage of residency, which lasts about a year and three months, consists basically of hospital internships, developed at the FMUSP's Clinical Hospital. This stage was structured based on the medical residency programs that are traditionally developed in this teaching hospital, with the collaboration of their coordinators. This step is focused on training the propaedeutics used by the various specialties as well as on discussing its specific behaviors. It can be developed in the urgency/emergency sectors, hospital wards and/or ambulatories ${ }^{3}$.

There are currently two ways to obtain acknowledgment as a Occupational Medicine Specialist by the Federal Board of Medicine: the specialist must have completed Medical Residency in an institution accredited by the CNRM or have passed the test for the title of Specialist issued by the AMB/ANAMT. For test for the title of Specialist in Occupational Medicine, a two-year in-service training in the specialty with total workload of 3840 hours or the practice of the occupational medicine specialty for four years is required. The title of specialist in Occupational Medicine is considered by the Occupational Medicine National Association as one of the best ways to show the whole society and particularly to the medical community the professional qualifications required to act with competence in the medical field related to labor health and safety. The Occupational Medicine Residency Program was implemented in 2004 and features theoretical and practical activities for the resident physicians, who are interns in clinical areas, in public and private companies ${ }^{4,5}$.

The areas of interest that form our lines of research include the study of current issues in Legal Medicine, Medical Ethics and Occupational Health. Its main goal is to provide the subsidies needed for the understanding and integrated performance of these fields of knowledge, to prioritize training and improvement of teachers and researchers from different academic backgrounds, and also to develop projects properly integrated with their related areas, aiming at a joint action. The Department's research groups are divided, in part, by the areas of activity of the subjects although some teachers develop research in more than one area. Some of these groups are represented in the National Council for Scientific and Technological Development (Conselho Nacional de Desenvolvimento Cientifico e Tecnológico- CNPq). Thus, the line of research on Human identification has been benefiting this chapter of Legal Medicine with the advance of molecular biology and DNA analysis techniques, especially with the research on polymorphic genetic markers that can be characterized in 
traces of biological fluids such as blood, sperm, saliva, cells from peeling, nasal secretion, fragmented human remains, ancient bones. In this research and included the cases of paternity investigation, identification of victims of major accidents, identification of charred bodies, etc.

In our department, the genomic and mitochondrial DNA analysis in human bone aims to optimize the extraction and amplification of DNA from compact bone from humans, exhumation material with medical and legal purposes through the identification of polymorphisms in genomic and mitochondrial DNA ${ }^{6}$.

The line of research on Genetic Polymorphisms in the Brazilian Population aims to know the frequencies of polymorphic genetic markers in the Brazilian population. Knowing these frequencies is of paramount importance in any population that has not been studied yet. This data will be essential in order to verify, for example, the possibility of genetic linkage in human identification.

The incidence of sexual crimes, followed by death or not, has increased significantly in our country, particularly in metropolitan areas. The "Identification of genetic polymorphisms in sperm from vasectomized individuals: medical and legal implications" research project aims to contribute to the care for victims of sexual crimes, especially in the identification of sex offenders through their sperm, even in vasectomized aggressors.

The impact of the Human Genome Project has resulted in the development of new systems of genetic markers and technological analysis. Therefore, the forensic science should position itself strategically to take advantage of these advances. From the beginning of the sequencing of the human genome, sequences which display a higher degree of polymorphism were considered to be extremely useful for DNA analysis in forensic cases and paternity tests. Due to the fact that most of the samples suffered some kind of damage, resulting in little material and/ or low quality material (degradation) for DNA analysis, molecular biology techniques that can overcome such barriers are required. A new class of markers, the SNPs (Single Nucleotides Polymorphisms), has revolutionized the human molecular genetics displaying a thick panel of genetic markers distributed throughout the entire genome. SNPs account for $90 \%$ of all polymorphisms in the human genome. On average, there is one SNP for every $\mathrm{kb}$ in the human genome, the mutation rate of the SNPs is extremely low, non-sex-specific transmission, the SNPs are stably inherited and their detection and analysis are extremely easy and fast. Thus, the "The use of new genetics and molecular biology methodologies in legal medicine" project aims to implement analysis using SNPs and mtDNA and the information generated will enable the expansion of the techniques available in the laboratory and a better interpretation of results in forensic cases which are directed to us? ${ }^{7}$.

In Legal Medicine, the line of research on issues related to civil law, especially with regard to medical error, stands out; the same occurs with the relationship between violence and drug abuse by different approaches, mainly traffic accidents, due to its great social and legal importance in our country.

In this sense, the goal of the "Psychoactive Substances in traffic accident victims on the highways of the State of São Paulo" study is to verify the frequency of the previous use of psychoactive substances (alcohol, cocaine, amphetamines and marijuana) by victims of traffic accidents in the highways of the State of São Paulo.

The activities of the Department in the extension area include, apart from the specialization courses, dissemination courses (organized and taught by the Department professors) conducted in other institutions in different parts of the national territory. There is collaboration with professors from other requesting institutions, providing guidance for the preparation of didactic material, especially classes with modern audio visual resources. The Department's professors are also required to attend interviews for radio programs, television and press media on current issues which are usually controversial and thus require the participation of experts, such as Fantástico, a news broadcast of Globo TV channel. It featured a special story on the case Josef Mengele (the doctor known as the "Angel of Death"), highlighting the performance of our department in the identification of his remains.

It also should be noted that the members of the Department are often required to attend medical examinations in the different areas of law, such as criminal, civil, labor and accident. Some of these examinations are among the most relevant not only in the national but also 
in the international scenario due to its impact.

Physiatrics was the latest area to be integrated to the Department. The care model developed by FMUSP's Physical Medicine and Rehabilitation served as a paradigm for the definition of the National Health Policy for Persons with Disabilities - Ministry of Health - Decree 1060 of 06/05/02. In this official document the epidemiological and assistance data of the Rehabilitation Medicine Division of the FMUSP's Clinical Hospital (Divisão de Medicina de Reabilitação - DMR) are often cited in order to support the document. The ministerial ordinances that create the Network of Assistance to Persons with Disabilities (GM 818 and SAS 185) were developed and systematized from the DMR's attendance experience and coordinated by the FMUSP. By setting assistance to persons with disabilities as a strategic action, the Ministry of Health has created a specific funding mechanism for the research activities and assistance to this segment. Within programs, the funds for the implementation of Rehabilitation centers for remote assistance to the disabled person - the Ministry of Health's Telemedicine Project - were obtained. The last course taught was the one on Assessment of Disability and Inability according to the criteria of the World Health Organization (WHO) - Taught by Professor Maria Angeles Hernandes Milagro (Autonomous University of Madrid) ${ }^{8}$.

\section{REFERENCES}

1- Lipp MEN. Resgatando a memória dos pioneiros: Oscar Freire de Carvalho (Salvador, *03/10/1882 - São Paulo, $\dagger 11 / 01 / 1923)$. Bol Acad Paul Psicol. 2008;28(2):15864. Disponível em: http://www.redalyc.org/articulo. oa?id=94628203.

2- Cohen C, Gobbetti GJ. O incesto: o abuso sexual intrafamiliar. São Paulo; 2010. Disponível em: http://www.usp.br/cearas/ ARTIGOS/oIncestoOabusoSexualIntrafamiliar.htm.

3- Muñoz DR, Gianvecchio VAP. Residência médica em medicina legal: objetivos. Saúde Ética Justiça. 2005;10(12):6-11. doi: http://dx.doi.org/10.11606/issn.2317-2770. v10i1-2p6-11.

4- Conselho Federal de Medicina, Resolução 1845 de 15 de julho de 2008. Disponível em: http://www.portalmedico.org. br/resolucoes/CFM/2008/1845_2008.htm.

5- Capo R, Almeida J, Rocha LE. A residência médica em medicina do trabalho na Faculdade de Medicina da Universidade de São Paulo. Rev Med (São Paulo). 2011;90(3):108-21. doi:http://dx.doi.org/10.11606/issn.16799836.v90i3p108-121.

6- Iwamura ESM, Soares-Vieira JA, Muñoz DR. Identificação humana e análise de DNA em ossos. Rev Hosp Clin. 2004. http://dx.doi.org/10.1590/S0041-87812004000600012.

7- Lloyd-Price J, Abu-Ali G, Huttenhower C. The healthy human microbiome. Genome Med. 2016;8:51. doi: 10.1186/ s13073-016-0307-y.

8- Lin TY, Stump P, Kaziyama HHS, Teixeira MJ, Imamura M, Greve JMA. Medicina física e reabilitação em doentes com dor crônica. Rev Med (São Paulo). 2001;80(ed. esp. pt.2):245-55. http://dx.doi.org/10.11606/issn.1679-9836. v80ispe2p245-255. 